\title{
EKSPERIMENTASI MODEL PEMBELAJARAN \\ INQUIRY LEARNING DAN DISCOVERY LEARNING TERHADAP PRESTASI BELAJAR DAN KEMAMPUAN KOMUNIKASI MATEMATIS PADA MATERI BANGUN RUANG SISI DATAR DITINJAU DARI KECERDASAN SPASIAL SISWA KELAS VIII SMP NEGERI SE-KOTA SURAKARTA
}

\author{
Abdul Aziz ${ }^{1}$, Budiyono ${ }^{2}$, Sri Subanti ${ }^{3}$ \\ ${ }^{1,2,3}$ Prodi Magister Pendidikan Matematika, FKIP Universitas Sebelas Maret Surakarta
}

\begin{abstract}
The purpose of this research was to know the effect of the learning models on the learning achievement and mathematics communication ability viewed from the spatial quotient. The learning models compared were Inquiry learning, Discovery learning and Classical model. The type of this study was a quasi-experimental study with a $3 \times 3$ factorial design. The study population was all grade VIII students of Junior High School in Solo city. Sample was collected by stratified cluster random sampling and consisted of 260 students which where divided into three groups, 86 students in Experimental Group 1,86 students in Experimental Group 2, and 88 students in Control Group . The instruments of the research include mathematics achievement test, mathematics communication ability test and spatial intelligence test. The technique of analyzing data used the two-way multivariate analysis of variance with unbalanced cell. The results of this research could be concluded as follows , (1) Inquiry Learning and Discovery Learning have better learning achievement and mathematics communication ability aspects than the Classical learning, Besides that, Inquiry Learning and Discovery Learning have the same learning achievement and mathematics communication ability; (2) The students with high spatial intelligence have the same learning achievement and mathematics communication ability as middle spatial intelligence. In addition, students who have high and middle spatial intelligence have better learning achievement and mathematics communication ability than students who have low spatial intelligence.; (3) In each learning model, the students with high and middle spatial intelligence have better learning achievement and mathematics communication ability than students who have low spatial intelligence, and the students with high and middle spatial intelligence have the same learning achievement and mathematics communication ability; (4) In each of the spatial intelligence, the cooperative learning model of Inquiry Learning and Discovery Learning give a better learning achievement and mathematics communication ability than the Classical model, and the cooperative learning model of Inquiry Learning and Discovery Learning give the same learning achievement and mathematics communication ability. Keywords: Inquiry Learning, Discovery Learning, Spatial Quotient, Learning Achievement, Mathematics Communication Ability.
\end{abstract}

\section{PENDAHULUAN}

Peradaban suatu negara akan mengalami kemajuan cukup pesat apabila warga negara tersebut dapat mempelajari, memahami, mengembangkan dan menerapkan kaidah-kaidah keilmuan matematika dalam berbagai aspek kehidupan dengan baik. Masalah klasik yang hingga kini masih terus diupayakan untuk perbaikannya adalah masih rendahnya prestasi belajar matematika peserta didik pada berbagai jenjang pendidikan dasar hingga menengah.

Salah satu kota di Indonesia yang peserta didiknya mempunyai prestasi belajar matematika rendah adalah kota Surakarta. Data PAMER 2014 menunjukkan bahwa 
penguasaan materi soal matematika ujian nasional tingkat SMP/MTS Tahun Pelajaran 2013/2014 masih rendah, khususnya dalam memahami sifat dan unsur bangun ruang dan menggunakannya dalam pemecahan masalah. Daya serap peserta didik dalam menguasai pokok bahasan ini sebesar 59,92\% masih di bawah rata-rata nasional sebesar 60,58\%.

Peserta didik yang mempunyai prestasi belajar matematika rendah khususnya dalam memahami materi geometri atau bangun ruang disebabkan karena pada proses pembelajaran yang berlangsung belum berjalan maksimal dan tepat guna. Hal ini mengindikasikan peserta didik masih belum menguasai secara menyeluruh sifat-sifat bangun ruang sisi datar, sehingga dalam aplikasinya untuk pengerjaan soal yang dipadukan dengan perhitungan volume, luas dan keliling bangun ruang sisi datar peserta didik masih kesulitan dalam menyelesaikan persoalan yang berkaitan dengan konsep tersebut.

Rendahnya prestasi belajar matematika siswa ini dipengaruhi oleh banyak faktor yang berkaitan dengan proses pembelajaran di sekolah seperti materi pembelajaran terlalu abstrak dan kurang menarik, metode pengajaran yang selalu berpusat pada guru sehingga siswa cenderung pasif dan tidak mempunyai kesempatan untuk berfikir secara matematis (Slameto, 2003). Dengan kondisi seperti ini, paradigma proses pembelajaran yang lebih menitikberatkan pada hasil perlahan mulai diubah untuk mengarahkan proses pembelajaran yang berkualitas dan bermakna. Peran guru dan peserta didik harus actionable secara berkesinambungan dan memiliki timbal balik yang positif.

Di samping prestasi belajar, dalam proses pembelajaran juga mencakup kegiatan komunikasi. Komunikasi adalah bagian yang cukup penting dari matematika dan pendidikan matematika (Hirschfeld, 2008:4) dalam Dona P. (2013). Melalui komunikasi, peserta didik dapat menyampaikan ide yang dimiliki dan memperjelas pemahaman terkait apa yang sedang dipelajari. Peserta didik dapat mengembangkan kemampuan berkomunikasi dengan menyampaikan bahasa, baik secara tertulis maupun lisan kaitannya dengan hal-hal yang bersifat matematis, sehingga komunikasi matematis dapat diartikan sebagai cara penyampaian ide dengan bahasa dan simbol matematis.

Kebanyakan model pembelajaran yang digunakan guru dalam proses belajar mengajar masih belum optimal untuk meningkatkan pemahaman atau potensi pada diri peserta didik sehingga prestasi belajar matematika yang didapatkan masih rendah. Kecenderungan dalam penerapan model pembelajaran, guru masih berperan sentral dalam proses pengajaran dan keterlibatan siswa masih belum terlihat secara optimal.

Salah satu faktor keberhasilan dalam meningkatkan prestasi belajar peserta didik adalah dengan melibatkan langsung kontribusi mereka dalam proses pengajaran dengan pemanfaatan model pembelajaran yang tepat. Guru yang berhasil adalah guru yang bisa 
menerapkan model pembelajaran yang sesuai dengan karakteristik peserta didik dan dapat memberikan dampak positif melalui peran peserta didik yang semakin luas dalam proses pendidikan.

Berkaitan dengan pemahaman materi bangun ruang peserta didik yang masih rendah, maka model pembelajaran yang cocok digunakan adalah model pembelajaran konstruktivisme. Pembelajaran constructivisme merupakan proses pembelajaran yang menerangkan bagaimana pengetahuan disusun dalam diri manusia (Ali Hamzah \& Muhlisrarini, 2014). Berdasarkan paham konstruktivisme, dalam proses belajar mengajar, guru tidak serta merta memindahkan pengetahuan kepada peserta didik dalam bentuk yang serba sempurna. Dengan kata lain, peserta didik harus membangun suatu pengetahuan itu berdasarkan pengalamannya masing-masing. Dengan kata lain suatu proses pembelajaran dapat dikatakan efektif dan bermakna apabila dalam proses kegiatan belajar mengajar peserta didik dapat menciptakan pembelajaran yang dapat menjadi pengalaman, seperti yang diungkapkan Dheeraj dan Kumari (2013:1) bahwa :

The constructivists proposed several instructional strategies, among the cooperative learning, collaborative learning, problem based learning etc. are prominent. Therefore, to keep pace with the changing circumstances, we should not keep ourselves aloof from new experiments in the field of education to make learning more effective and enjoyable experience for pupils.

Terdapat beberapa model pembelajaran konstruktivisme yang telah dikembangkan oleh para ahli dan praktisi pendidikan, diantaranya adalah model pembelajaran berbasis penemuan yang dilakukan secara kooperatif oleh peserta didik. Melalui kajian yang dilakukan oleh Wilcox (Slavin, 1977) dalam M. Hosnan (2014) pada pembelajaran berbasis penemuan, peserta didik mampu berperan aktif dan berkontribusi besar selama proses pembelajaran melalui percobaan-percobaan yang telah dilakukan secara kooperatif sehingga peserta didik dapat menemukan prinsip dan konsep secara mandiri dan terbentuk suatu pengetahuan baru dalam diri mereka.

Model pembelajaran berbasis penemuan yang telah dikembangkan oleh pakar pendidikan di antaranya adalah inquiry learning dan discovery learning. Kedua model pembelajaran tersebut sudah teruji untuk meningkatkan peran serta peserta didik dalam proses pembelajaran, sehingga prestasi belajar dapat dimaksimalkan.

Model pembelajaran inkuiri (inquiry learning) menekankan kepada proses mencari dan menemukan. Peran peserta didik dalam metode ini adalah mencari dan menemukan sendiri materi pelajaran, sedangkan pendidik berperan sebagai fasilitator dan pembimbing peserta didik untuk belajar. Pembelajaran inkuiri merupakan rangkaian kegiatan pembelajaran yang menekankan pada proses berpikir kritis dan analitis untuk mencari dan menemukan sendiri jawaban dari suatu masalah yang dipertanyakan. 
Selain model inquiry learning, model pembelajaran yang tepat digunakan dalam pembelajaran untuk membahas materi bangun ruang sisi datar adalah model discovery learning dan juga merupakan suatu model pembelajaran yang dikembangkan berdasarkan pandangan konstruktivisme. Sebagai model pembelajaran, discovery learning mempunyai prinsip yang sama dengan inquiry learning. Tidak ada perbedaan yang prinsipil pada kedua istilah ini, pada discovery learning lebih menekankan pada ditemukannya konsep atau prinsip yang sebelumnya tidak diketahui. Perbedaan discovery dan inquiry dapat dilihat pada permasalahan yang diberikan oleh guru. Pada discovery masalah yang dihadapkan kepada peserta didik merupakan masalah yang direkayasa oleh guru. Sedangkan pada inquiry masalahnya bukan hasil rekayasa, sehingga peserta didik harus mengerahkan seluruh pikiran dan keterampilannya untuk mendapatkan temuan-temuan di dalam masalah itu melalui proses percobaan.

Penerapan model inquiry learning, discovery learning dan klasikal pada pembelajaran matematika merupakan salah satu upaya agar peserta didik dapat memecahkan masalah yang berkaitan dengan matematika, khususnya dalam penulisan ini peserta didik dapat menguasai konsep bangun ruang dengan baik.

Kegiatan pembelajaran diarahkan untuk memberdayakan semua potensi yang dimiliki peserta didik agar mereka dapat memiliki kompetensi yang diharapkan melalui upaya menumbuhkan serta mengembangkan; sikap/attitude, pengetahuan/knowledge, dan keterampilan/skill (M. Hosnan,2014). Kualitas lain yang dikembangkan kurikulum dan harus terealisasikan dalam proses pembelajaran di antaranya adalah meningkatkan inteligensi ganda (multiple intelligences) yang dimiliki oleh masing-masing peserta didik. Intelegensi ganda yang terdapat pada setiap individu peserta didik memegang peranan penting dalam mengoptimalkan potensi dan prestasi belajar mereka.

Salah satu jenis dari intelegensi ganda yaitu kecerdasan visual-spasial. Menurut M.Yaumi (2012), kecerdasan visual-spasial atau disebut kecerdasan spasial adalah kemampuan untuk memahami gambar-gambar dan bentuk termasuk kemampuan untuk menginterpretasi dimensi ruang yang tidak dapat dilihat. Kecerdasan spasial sebagian besar tergantung pada kemampuan untuk menggambar bentuk dan ruang dari suatu objek, merupakan kemampuan untuk memikirkan bentuk.

Berkaitan dengan kecerdasan spasial, penelitian yang telah dilakukan oleh Harmony dan Theis (2012) menyatakan bahwa terdapat interaksi antara kecerdasan spasial terhadap hasil belajar matematika siswa kelas VII. Siti Marliah Tambunan (2006) menyatakan bahwa terdapat hubungan antara kecerdasan spasial total, topologi dan euclidis dengan prestasi belajar matematika, tetapi tidak terdapat hubungan antara kecerdasan spasial proyektif dengan prestasi belajar matematika. Hoong dan Khoh (2012) 
menyatakan bahwa tingkat kecerdasan spasial memberikan efek yang signifikan terhadap prestasi belajar matematika.

Prestasi belajar dan kemampuan komunikasi peserta didik akan terlihat dalam proses pembelajaran dengan penerapan model inquiry learning dan discovery learning dengan salah satu multiple intelligences yang dimiliki oleh peserta didik yaitu kecerdasan spasial. Oleh karena itu, peneliti ingin mengetahui pengaruh penerapan model inquiry learning dan discovery learning ditinjau dari kecerdasan spasial terhadap prestasi belajar dan komunikasi matematis peserta didik.

Pada prinsipnya tujuan yang ingin dicapai dalam penelitian ini sebagai berikut : (1) Untuk mengetahui prestasi belajar dan kemampuan komunikasi matematis peserta didik manakah yang lebih baik, antara peserta didik yang pembelajarannya menggunakan model inquiry learning, discovery learning atau pembelajaran klasikal. (2) Untuk mengetahui pada pembelajaran materi bangun ruang sisi datar, prestasi belajar dan kemampuan komunikasi matematis peserta didik manakah yang lebih baik, antara peserta didik yang memiliki kecerdasan spasial tinggi, sedang atau rendah. (3) Untuk mengetahui pada masing-masing kecerdasan spasial, prestasi belajar dan kemampuan komunikasi matematis peserta didik manakah yang lebih baik, peserta didik yang dikenai model pembelajaran inquiry learning, discovery learning atau pembelajaran klasikal. (4) Untuk mengetahui pada masing-masing model pembelajaran, prestasi belajar dan kemampuan komunikasi matematis peserta didik manakah yang lebih baik, peserta didik yang memiliki kecerdasan spasial tinggi, sedang atau rendah.

\section{METODE PENELITIAN}

Jenis penelitian ini merupakan penelitian eksperimental semu dengan desain faktor penelitian 3 x 3. Populasi penelitian ini adalah seluruh siswa kelas VIII SMP Negeri seKota Surakarta dengan pengambilan sampel menggunakan teknik stratified cluster random sampling. Sampel yang diperoleh adalah siswa kelas VIII SMP Negeri 7 Surakarta untuk kategori sekolah tinggi, SMP Negeri 14 Surakarta untuk kategori sekolah sedang, dan SMP Negeri 20 Surakarta untuk kategori sekolah rendah.

Variabel terikat dalam penelitian ini yaitu prestasi belajar dan komunikasi matematis, sedangkan variabel bebasnya yaitu model pembelajaran dan kecerdasan spasial peserta didik. Teknik pengumpulan data yang digunakan dalam penelitian ini yaitu metode dokumentasi dan tes. Metode dokumentasi digunakan untuk mengumpulkan data kemampuan awal peserta didik yang diambil dari nilai ujian akhir semester gasal tahun pelajaran 2014 / 2015 sebagai data awal prestasi belajar. Metode tes digunakan untuk mengukur prestasi belajar, kemampuan komunikasi matematis dan kecerdasan 
spasial. Tes yang digunakan untuk mengukur prestasi belajar dan komunikasi matematis setelah perlakuan menggunakan materi kubus dan balok, sedangkan tes untuk mengukur komunikasi matematis awal menggunakan materi lingkaran, sedangkan tes untuk kecerdasan spasial menggunakan soal-soal pilihan ganda didapatkan dari soal psikotes dan sumber lain yang dapat digunakan sebagai acuan untuk mengukur kecerdasan spasial peserta didik.

Sebelum dilakukan perlakuan terhadap sampel, dilakukan uji keseimbangan dengan menggunakan uji analisis variansi multivariat satu jalan sel tak sama dan disimpulkan bahwa ketiga sampel memiliki kemampuan awal yang sama atau seimbang.

Instrumen tes yang digunakan dalam penelitian terlebih dahulu dilakukan validasi isi, uji konsistensi internal, uji daya pembeda, dan uji reliabilitas untuk mengetahui kelayakan butir soal tes. Uji hipotesis penelitian dilakukan dengan uji analisis variansi multivariat dua jalan sel tak sama. Untuk uji prasyarat sebelum uji hipotesis mencakup uji normalitas univariat dan multivariat, selanjutnya dilakukan uji homogenitas variansi dan uji kesamaan matriks variansi kovariansi. Setelah dilakukan uji hipotesis, langkah berkutnya melakukan uji lanjut dengan analisis variansi dua jalan sel tak sama, untuk mengetahui kesimpulan akhir dilanjutkan uji komparasi ganda dengan metode Scheffe'.

\section{HASIL PENELITIAN DAN PEMBAHASAN}

Melalui data penelitian, dilakukan uji keseimbangan, setelah itu uji prasyarat kemudian dilanjutkan dengan uji hipotesis dengan uji Wilks'. Berdasarkan hasil analisis, diperoleh statistik uji $F_{o b s}=0,24$ dan $F_{\alpha}=2,38, F_{o b s} \leq F_{\alpha}$, akibatnya $F_{\text {obs }} \notin D K$. Jadi, dapat disimpulkan untuk taraf signifikansi 5\% semua populasi memiliki kemampuan awal yang sama atau dalam keadaan seimbang. Untuk hasil uji normalitas univariat dan multivariat dapat disimpulkan bahwa populasi berdistribusi normal univariat dan multivariat. Untuk uji homogenitas variansi dan uji kesamaan matriks variansi kovariansi data penelitian menunjukkan bahwa populasi mempunyai variansi dan matriks variansi kovariansi yang sama. Rangkuman uji analisis variansi multivariat dua jalan dengan sel tak sama dapat dilihat pada Tabel 1. 
Tabel 1. Rangkuman Analisis Variansi Multivariat Dua Jalan dengan Sel Tak Sama

\begin{tabular}{|c|c|c|c|c|c|c|c|}
\hline $\begin{array}{l}\text { Sumber } \\
\text { Variasi }\end{array}$ & Matriks SSCP & & $d k$ & $\Lambda$ & $F_{o b s}$ & $F_{\alpha}$ & Kep Uji \\
\hline Faktor A & $H_{A}=\left[\begin{array}{c}17588,43 \\
17270,1\end{array}\right.$ & $\left.\begin{array}{c}17270,1 \\
17771,28\end{array}\right]$ & 2 & 0,706 & 11,23 & 2,389 & $\begin{array}{l}H_{0} \mathrm{~A} \\
\text { ditolak }\end{array}$ \\
\hline Faktor B & $H_{B}=\left[\begin{array}{l}7593,37 \\
7959,03\end{array}\right.$ & $\left.\begin{array}{l}7959,03 \\
8465,17\end{array}\right]$ & 2 & 0,851 & 23,46 & 2,389 & $\begin{array}{l}H_{0} \mathrm{~B} \\
\text { ditolak }\end{array}$ \\
\hline Interaksi & $H_{A B}=\left[\begin{array}{l}3895,20 \\
2733,87\end{array}\right.$ & $\left.\begin{array}{l}2733,87 \\
2230,51\end{array}\right]$ & 4 & 0,953 & 0,981 & 1,957 & $\begin{array}{l}H_{0} \\
\text { diterima }\end{array}$ \\
\hline Galat & $H_{E}=\left[\begin{array}{l}55715,66 \\
43534,71\end{array}\right.$ & $\left.\begin{array}{l}43534,71 \\
51907,83\end{array}\right]$ & 251 & - & - & - & - \\
\hline Total & $T=\left[\begin{array}{l}84792,67 \\
71497,72\end{array}\right.$ & $\left.\begin{array}{l}71497,72 \\
80374,79\end{array}\right]$ & 260 & - & - & - & - \\
\hline
\end{tabular}

Berdasarkan Tabel 1, dapat disimpulkan bahwa: (1) terdapat perbedaan efek antar model pembelajaran terhadap prestasi belajar dan komunikasi matematis, (2) terdapat perbedaan efek antar kecerdasan spasial terhadap prestasi belajar dan komunikasi matematis, serta (3) tidak ada interaksi antara model pembelajaran dan kecerdasan spasial terhadap prestasi belajar dan komunikasi matematis. Tabel 1 menunjukkan bahwa $H_{O A}$ ditolak, $H_{O B}$ ditolak, dan $H_{O A B}$ diterima. Dengan demikian, perlu adanya uji lanjut pada setiap variabel terikat yakni prestasi belajar $\left(X_{1}\right)$ dan komunikasi matematis $\left(X_{2}\right)$ dengan uji analisis variansi dua jalan sel tak sama. Berikut ditunjukkan rangkuman uji analisis variansi dua jalan sel tak sama pada setiap variabel bebas model pembelajaran (A) dan kecerdasan spasial (B) pada Tabel 2.

\section{Tabel 2. Rangkuman Analisis Variansi Univariat Dua Jalan Sel Tak Sama}

\begin{tabular}{|c|c|c|c|c|c|c|c|}
\hline $\begin{array}{l}\text { Sumber } \\
\text { Variasi }\end{array}$ & $\begin{array}{l}\text { Var. } \\
\text { Terikat }\end{array}$ & $J K$ & $D k$ & $R K$ & $F_{o b s}$ & $F_{\alpha}$ & Keputusan Uji \\
\hline \multirow{2}{*}{ Baris (A) } & $X_{1}$ & 9800,98 & 2 & 4900,49 & 18,101 & 3,032 & $H_{0 \mathrm{~A}}$ ditolak \\
\hline & $X_{2}$ & 14863,40 & 2 & 7431,70 & 25,692 & 3,032 & $H_{0 \mathrm{~A}}$ ditolak \\
\hline \multirow{2}{*}{ Kolom $(B)$} & $X_{1}$ & 23129,68 & 2 & 11564,84 & 42,718 & 3,032 & $H_{0 \mathrm{~B}}$ ditolak \\
\hline & $X_{2}$ & 18460,40 & 2 & 9230,20 & 31,91 & 3,032 & $H_{0 \mathrm{~B}}$ ditolak \\
\hline \multirow{2}{*}{$\begin{array}{l}\text { Interaksi } \\
(A B)\end{array}$} & $X_{1}$ & 2250,30 & 4 & 562,574 & 2,078 & 2,408 & $H_{0 \mathrm{AB}}$ diterima \\
\hline & $X_{2}$ & 1990,06 & 4 & 497,515 & 1,720 & 2,408 & $H_{0 \mathrm{AB}}$ diterima \\
\hline \multirow{2}{*}{ Galat } & $X_{1}$ & 67951,69 & 251 & 270,724 & - & - & - \\
\hline & $X_{2}$ & 72603,92 & 251 & 289,259 & - & - & - \\
\hline \multirow{2}{*}{ Total } & $X_{1}$ & 103132,66 & 259 & - & - & - & - \\
\hline & $X_{2}$ & 107917,79 & 259 & - & - & - & - \\
\hline
\end{tabular}

Berdasarkan hasil analisis variansi univariat dua jalan sel tak sama diketahui bahwa pada model pembelajaran dan kecerdasan spasial pada setiap variabel terikat $F_{o b s}>F_{\alpha}$, akibatnya $F_{\text {obs }} \in D K$ sehingga $H_{0 \mathrm{~A}}$ dan $H_{0 \mathrm{~B}}$ ditolak, sedangkan pada efek interaksi $F_{o b s} \leq$ $F_{\alpha}$, akibatnya $F_{\text {obs }} \notin D K$ sehingga $H_{0 \mathrm{AB}}$ diterima, maka dengan taraf signifikansi $5 \%$ 
dapat disimpulkan bahwa: (1) terdapat perbedaan efek antar model pembelajaran terhadap prestasi belajar dan kemampuan komunikasi matematis, (2) terdapat perbedaan efek antar kecerdasan spasial terhadap prestasi belajar dan kemampuan komunikasi matematis, dan (3) tidak ada interaksi antara model pembelajaran dan kecerdasan spasial terhadap prestasi belajar dan kemampuan komunikasi matematis.

Setelah diperoleh hasil uji univariat dua jalan sel tak sama yang menyatakan bahwa $H_{0 \mathrm{~A}}$ dan $H_{0 \mathrm{~B}}$ ditolak, maka untuk mengetahui manakah perlakuan yang secara signifikan berbeda dari yang lainnya dilakukan uji komparasi ganda pada setiap variabel terikat. Pada penelitian ini, uji komparasi ganda yang digunakan adalah metode Scheffé. Sebelum berlanjut ke uji komparasi ganda, maka disajikan rerata marginal pada setiap sel pada Tabel 3.

Tabel 3. Rerata Data Penelitian

\begin{tabular}{|c|c|c|c|c|c|}
\hline \multirow{2}{*}{\multicolumn{2}{|c|}{$\begin{array}{l}\text { Model Pembelajaran } \\
\text { (Faktor } A \text { ) }\end{array}$}} & \multicolumn{3}{|c|}{ Kecerdasan Spasial (Faktor $B)$} & \multirow{2}{*}{$\begin{array}{l}\text { Rerata } \\
\text { Marginal } \\
\text { Baris }\end{array}$} \\
\hline & & Tinggi & Sedang & Rendah & \\
\hline \multirow{2}{*}{$\begin{array}{l}\text { Inquiry } \\
\text { Learning }\end{array}$} & Prestasi Belajar $\left(X_{1}\right)$ & 73,826 & 70,826 & 50 & 61,942 \\
\hline & $\begin{array}{l}\text { Komunikasi } \\
\text { Matematika }\left(X_{2}\right)\end{array}$ & 73,098 & 70,036 & 48,214 & 60,667 \\
\hline \multirow{2}{*}{$\begin{array}{l}\text { Discovery } \\
\text { Learning }\end{array}$} & Prestasi Belajar $\left(X_{1}\right)$ & 72,727 & 71,277 & 58,560 & 63,47 \\
\hline & $\begin{array}{l}\text { Komunikasi } \\
\text { Matematika }\left(X_{2}\right)\end{array}$ & 70,682 & 62,628 & 59,00 & 63,64 \\
\hline \multirow[b]{2}{*}{ Klasikal } & Prestasi Belajar $\left(X_{1}\right)$ & 63,900 & 69,820 & 45,920 & 51,707 \\
\hline & $\begin{array}{l}\text { Komunikasi } \\
\text { Matematika }\left(X_{2}\right)\end{array}$ & 57,875 & 61,644 & 42,45 & 49,048 \\
\hline Rerata & Prestasi Belajar $\left(X_{1}\right)$ & 71,151 & 70,477 & 51,490 & 64,372 \\
\hline $\begin{array}{l}\text { Marginal } \\
\text { Kolom }\end{array}$ & $\begin{array}{l}\text { Komunikasi } \\
\text { Matematika }\left(X_{2}\right)\end{array}$ & 66,30 & 65,020 & 50,580 & 60,633 \\
\hline
\end{tabular}

Tahapan berikutnya disajikan rangkuman uji komparasi ganda antar baris dengan metode Scheffe' pada masing-masing variabel terikat pada Tabel 4.

Tabel 4. Rangkuman Komparasi Rerata Antar Baris

Variabel terikat: prestasi belajar

\begin{tabular}{llll}
\hline$H_{0}$ & $F_{\text {obs }}$ & $(a-1) F_{\alpha}$ & Keputusan Uji \\
\hline$\mu_{11}=\mu_{12}$. & 0,307 & 6,064 & $H_{0}$ diterima \\
$\mu_{11}=\mu_{13 .}$ & 13,945 & 6,064 & $H_{0}$ ditolak \\
$\mu_{12}=\mu_{13 .}$ & 18,419 & 6,064 & $H_{0}$ ditolak \\
\hline
\end{tabular}

Variabel terikat: komunikasi matematika

\begin{tabular}{llll}
\hline$H_{0}$ & $F_{\text {obs }}$ & $(a-1) F_{\alpha}$ & Keputusan Uji \\
\hline$\mu_{21}=\mu_{22}$ & 2,048 & 6,064 & $H_{0}$ diterima \\
$\mu_{21}=\mu_{23 .}$ & 14,837 & 6,064 & $H_{0}$ ditolak \\
$\mu_{22}=\mu_{23 .}$ & 27,998 & 6,064 & $H_{0}$ ditolak \\
\hline
\end{tabular}


Berdasarkan Tabel 3 dan Tabel 4, diperoleh kesimpulan sebagai berikut: (1) peserta didik yang dikenai model pembelajaran inquiry learning dan discovery learning mempunyai prestasi belajar yang lebih baik daripada peserta didik yang dikenai model pembelajaran klasikal dan peserta didik yang dikenai model inquiry learning dan discovery learning mempunyai prestasi belajar yang sama; (2) peserta didik yang dikenai model pembelajaran inquiry learning dan discovery learning memperoleh kemampuan komunikasi matematis yang lebih baik daripada peserta didik yang dikenai model pembelajaran klasikal dan peserta didik yang dikenai model inquiry learning dan discovery learning memperoleh kemampuan komunikasi matematis yang sama.

Untuk uji komparasi ganda antar kolom pada setiap variabel terikat yakni pengetahuan dan keterampilan disajikan dalam Tabel 5.

Tabel 5. Rangkuman Komparasi Rerata Antar Kolom

Variabel Terikat: Prestasi Belajar

\begin{tabular}{llll}
\hline$H_{0}$ & $F_{\text {obs }}$ & $(b-1) F_{\alpha}$ & Keputusan Uji \\
\hline$\mu_{1.1}=\mu_{1.2}$ & 2,312 & 6,064 & $H_{0}$ diterima \\
$\mu_{1.1}=\mu_{1.3}$ & 42,23 & 6,064 & $H_{0}$ ditolak \\
$\mu_{1.2}=\mu_{1.3}$ & 32,39 & 6,064 & $H_{0}$ ditolak \\
\hline \multicolumn{4}{c}{ Variabel Terikat: Komunikasi Matematika } \\
\hline$H_{0}$ & $F_{\text {obs }}$ & $(b-1) F_{\alpha}$ & Keputusan Uji \\
\hline$\mu_{2.1}=\mu_{2.2}$ & 3,91 & 6,064 & $H_{0}$ diterima \\
$\mu_{2.1}=\mu_{2.3}$ & 27,25 & 6,064 & $H_{0}$ ditolak \\
$\mu_{2.2}=\mu_{2.3}$ & 14,45 & 6,064 & $H_{0}$ ditolak \\
\hline
\end{tabular}

Berdasarkan Tabel 3 dan Tabel 5, diperoleh kesimpulan sebagai berikut: (1) prestasi belajar peserta didik dengan kecerdasan spasial tinggi dan sedang lebih baik daripada peserta didik dengan kecerdasan spasial rendah, dan prestasi belajar peserta didik dengan kecerdasan spasial tinggi dan sedang sama; (2) kemampuna komunikasi matematis peserta didik dengan kecerdasan spasial tinggi dan sedang lebih baik daripada peserta didik dengan kecerdasan spasial rendah, dan kemampuan komunikasi matematis peserta didik dengan kecerdasan spasial tinggi dan sedang sama.

Terdapat kesesuian antara hipotesis penelitian dan hasil penelitian yang menyatakan bahwa model Inquiry Learning dan Discovery Learning menghasilkan prestasi belajar dan kemampuan komunikasi matematis yang lebih baik dari pada model pembelajaran klasikal, akan tetapi model pembelajaran Inqury dan model pembelajaran Discovery menghasilkan prestasi belajar dan kemampuan komunikasi matematis yang sama. Hasil temuan ini dipengaruhi oleh karakteristik model pembelajaran Inquiry dan Discovery yang mengarahkan peserta didik untuk berfikir kritis, kreatif dan inofativ 
dalam rangka menemukan hal-hal baru yang berkaitan dengan materi pelajaran yang sedang dipelajari. Dengan demikian, peserta didik dapat meningkatkan pengalamannya dalam pembelajaran dan ini akan menjadi sesuatu yang positif dalam proses pembelajaran. Sejalan dengan hasil penelitian yang dilakukan oleh Abdelrahem \& Asan (2006) yang menyimpulkan bahwa,

"inquiry-based technology enhanced collaborative learning environment can enhance students learning experiences".

Peserta didik menjadi subjek pendidikan dan berperan sentral serta dapat mengkonstruksikan sendiri pengetahuan yang akan mereka dapatkan melalui proses pembelajaran. Pengajaran berdasarkan inkuiri berpusat pada peserta didik di mana mereka memiliki tugas untuk masuk ke dalam suatu isu ataupun mencari jawabanjawaban terhadap isi pertanyaan melalui suatu prosedur yang digariskan secara jelas dan dapat bekerja secara kelompok dengan baik (Kourilsky dalam Oemar ,2001). Pembelajaran penemuan merupakan model pembelajaran yang digunakan dalam pendekatan konstruktivis yang bertujuan untuk membimbing peserta didik lebih berperan aktif dalam proses pembelajaran. Cranton (Devi, 2014) menjelaskan bahwa dalam pembelajaran aktif, peserta didik tenggelam dalam pengalaman di mana mereka terlibat dalam pembuatan, penyelidikan, tindakan, imajinasi, penemuan, interaksi, hipotesa dan refleksi pribadi.

Dalam penelitian ini dengan menggunakan tinjauan kecerdasan spasial menunjukkan bahwa prestasi belajar dan kemampuan komunikasi matematis peserta didik dengan kecerdasan spasial tinggi lebih baik dari pada peserta didik dengan tingkat kecerdasan spasial rendah dan peserta didik dengan kecerdasan spasial sedang menghasilkan prestasi belajar dan kemampuan komunikasi matematis yang lebih baik daripada peserta didik dengan kecerdasan spasial rendah. Hasil temuan ini disebabkan karena perbedaan yang cukup signifikan antara tingkat kecerdasan spasial yang dimiliki peserta didik berkaitan erat dengan hasil belajar.

Hasil penelitian ini juga menunjukkan bahwa tidak adanya efek interaksi antara model pembelajaran dan kecerdasan spasial, sehingga dalam melihat keterkaitan pada setiap model pembelajaran dengan kecerdasan spasial mengacu pada hipotesis pertama dan kedua. Pada pembelajaran dengan model Inquiry Learning, peserta didik yang memiliki kecerdasan spasial tinggi memperoleh prestasi belajar dan kemampuan komunikasi matematis yang lebih baik dibandingkan dengan kecerdasan spasial rendah dan peserta didik yang memiliki kecerdasan spasial sedang mengasilkan prestasi belajar dan kemampuan komunikasi matematis yang lebih baik dibandingkan dengan kecerdasan spasial rendah sedangkan peserta didik yang memiliki kecerdasan spasial tinggi dan 
sedang menghasilkan prestasi belajar dan kemampuan komunikasi matematis yang sama. Pada pembelajaran dengan model Discovery Learning, peserta didik yang memiliki kecerdasan spasial tinggi memperoleh prestasi belajar dan kemampuan komunikasi matematis yang lebih baik dibandingkan dengan kecerdasan spasial rendah dan peserta didik yang memiliki kecerdasan spasial sedang mengasilkan prestasi belajar dan kemampuan komunikasi matematis yang lebih baik dibandingkan dengan kecerdasan spasial rendah sedangkan peserta didik yang memiliki kecerdasan spasial tinggi dan sedang menghasilkan prestasi belajar dan kemampuan komunikasi matematis yang sama. Sedangkan pada pembelajaran klasikal, peserta didik yang memiliki kecerdasan spasial tinggi memperoleh prestasi belajar dan kemampuan komunikasi matematis yang lebih baik dibandingkan dengan kecerdasan spasial rendah dan peserta didik yang memiliki kecerdasan spasial sedang mengasilkan prestasi belajar dan kemampuan komunikasi matematis yang lebih baik dibandingkan dengan kecerdasan spasial rendah sedangkan peserta didik yang memiliki kecerdasan spasial tinggi dan sedang menghasilkan prestasi belajar dan kemampuan komunikasi matematis yang sama. Peserta didik dengan kecerdasan spasial yang baik akan memperoleh prestasi belajar dan kemampuan komunikasi matematis yang optimal, karena dengan hal tersebut peserta didik dapat mengaplikasikannya pada situasi yang baru sesuai dengan pengetahuan dan tingkat kecerdasan spasialnya untuk kemedian dapat memberikan pengaruh terhadap hasil pembelajaran. Senada dengan penelitian yang dilakukan oleh Kamel (2014) yang menyatakan bahwa,

"discovery learning strategy helped to recruit activities where students learn for themselves and apply what know it in new situations; which in turn led to achieving effective learning"

Di samping itu dinyatakan pula bahwa tidak adanya efek interaksi antara setiap kecerdasan spasial dan model pembelajaran, sehingga dalam melihat keterkaitan pada setiap kecerdasan spasial dengan model pembelajaran mengacu pada hipotesis pertama dan kedua. Untuk peserta didik yang memiliki kecerdasan spasial tinggi, prestasi belajar dan kemampuan komunikasi matematis yang diperoleh sama jika diberikan pembelajaran dengan model Inquiry Learning dan Discovery Learning, dan prestasi belajar dan kemampuan komunikasi matematis peserta didik yang diperoleh akan lebih baik jika diberikan pembelajaran dengan model Inquiry Learning dan Discovery Learning dibandingkan dengan model pembelajaran klasikal. Untuk peserta didik yang memiliki kecerdasan spasial sedang, prestasi belajar dan kemampuan komunikasi matematis yang diperoleh sama jika diberikan pembelajaran dengan model Inquiry Learning maupun Discovery Learning, dan prestasi belajar dan kemampuan komunikasi matematis yang 
diperoleh akan lebih baik jika diberikan pembelajaran dengan model Inquiry Learning maupun Discovery Learning dibandingkan dengan model pembelajaran klasikal. Sedangkan untuk peserta didik yang memiliki kecerdasan spasial rendah, prestasi belajar dan kemampuan komunikasi matematis yang diperoleh sama jika diberikan pembelajaran dengan model Inquiry Learning dan Discovery Learning, dan prestasi belajar maupun kemampuan komunikasi matematis yang diperoleh akan lebih baik jika diberikan pembelajaran dengan model Inquiry Learning maupun Discovery Learning dibandingkan dengan model pembelajaran klasikal.

\section{SIMPULAN DAN SARAN}

Berdasarkan kajian teori dan hasil pembahasan serta rumusan masalah yang telah diuraikan di awal, maka disusun kesimpulan dalam penelitian ini sebagai berikut (1) Prestasi belajar dan kemampuan komunikasi matematis yang diperoleh peserta didik dalam pembelajaran berbasis penemuan, pada model Inquiry Learning dan model Discovery Learning lebih baik daripada model pembelajaran klasikal, dan model pembelajaran Inquiry sama baiknya dengan model pembelajaran Discovery. (2). Peserta didik dengan kecerdasan spasial tinggi memperoleh prestasi belajar dan kemampuan komunikasi matematis yang lebih baik daripada peserta didik yang mempunyai kecerdasan spasial rendah. Peserta didik dengan kecerdasan spasial sedang memperoleh prestasi belajar dan kemampuan komunikasi matematis yang lebih baik daripada peserta didik yang mempunyai kecerdasan spasial rendah, sedangkan peserta didik yang mempunyai kecerdasan spasial tinggi memperoleh prestasi belajar dan kemampuan komunikasi matematis yang sama baiknya dengan peserta didik yang memiliki kecerdasan spasial sedang. (3). Pembelajaran pada model Inquiry Learning, Discovery Learning, dan klasikal, peserta didik dengan kecerdasan spasial tinggi memiliki prestasi belajar dan kemampuan komunikasi matematis yang lebih baik dibandingkan dengan peserta didik dengan kecerdasan spasial rendah, dan peserta didik dengan kecerdasan spasial sedang memiliki prestasi belajar dan kemampuan komunikasi matematis yang lebih baik dibandingkan dengan peserta didik dengan kecerdasan spasial rendah, sedangkan peserta didik dengan kecerdasan spasial menghasilkan prestasi belajar dan kemampuan komunikasi matematis yang sama dengan peserta didik dengan kecerdasan spasial sedang. (4). Peserta didik yang memiliki kecerdasan spasial tinggi, sedang, dan rendah memiliki prestasi belajar dan kemampuan komunikasi matematis yang lebih baik jika diberikan pembelajaran berbasis penemuan dengan model pembelajaran inquiry dan discovery dibandingkan dengan model pembelajaran klasikal, dan prestasi belajar dan 
komunikasi matematika yang dikenai model pembelajaran inquiry sama baiknya dengan peserta didik yang dikenai model pembelajaran discovery.

Dalam penelitian ini memberikan suatu pemikiran yang berhubungan dengan peningkatan prestasi belajar dan kemampuan komunikasi matematis. Oleh karena itu, disarankan Guru sebaiknya menerapkan model pembelajaran inquiry dan discovery dalam proses pembelajarannya. Selain itu penulis berharap agar peneliti lain dapat mengembangkan penelitian dengan tinjauan yang berbeda.

\section{DAFTAR PUSTAKA}

Abdelraheem, A., \& Asan, A. (2006). The Effectiveness of Inquiry-Based Technology Enhanced Collaborative Learning Environment. International Journal of Technology in Teaching and Learning, 2 (2), 65-87. Sultan Qaboos University.

Ali Hamzah \& Muhlisrarini. 2014. Perencanaan Dan Strategi Pembelajaran Matematika. Jakarta: PT RajaGrafindo Persada.

Dheeraj, D. dan Kumari, R. 2013.” Effect of Co-operative Learning on Achievement in Enviromental Science of School Student". International Journal of scientific and Research Publications, 3(2):1-3.

Devi, A. S. 2014. Active Learning Models for Effective Teaching. India: Jawaharlal Nehru Technological University Hyderabad.

Dona D. P. 2013. Kemampuan Komunikasi Matematis Dalam Pemecahan Masalah Matematika Sesuai Dengan Gaya Kognitif Pada Siswa Kelas IX SMP Negeri 1 Surakarta Tahun Pelajaran 2012/2013. Tesis Pasca Sarjana Pendidikan Matematika UNS. Surakarta. Tidak dipublikasikan.

Harmony, J. \& Theis, R. 2012. Pengaruh Kemampuan Spasial Terhadap Hasil Belajar Matematika Siswa Kelas Vii Smp Negeri 9 Kota Jambi. Edumatica. Volume O2 Nomor 01, April 2012 ISSN: 2088-2157

Hoong, L.Y. \& Khoh, L.S, 2012. Effects of Geometer's Sketchpad on Spatial Ability and Achievement in Transformation Geometry among Secondary Two Students in Singapore. National Institute of Education, Nanyang Technological University, Singapore.

Hirschfeld, K. 2008. Mathematical Communication, Conceptual Understanding, and Student's Attitudes Toward Mathematics. In Partial Fulfillment of The MAT Degree. University of Nebraska-Lincoln.

Kamel A. (2014). The Effect of Using Discovery Learning in Teaching Grammatical Rules to First Year General Secondary Student on Developing Their Achivement and Metacognitive Skills. International Journal of Innovation and Scientific Research. ISSN 2351-8014 Vol. 5 No. 2Juli 2014,pp.146-153. 
M.Hosnan. 2014. PENDEKATAN SAINTIFIK DAN KONTEKSTUAL DALAM PEMBELAJARAN ABAD 21. Bogor: Ghalia Indonesia.

M. Yaumi. 2012. Pembelajaran Berbasis Multiple Intelligences. Jakarta : PT Dian Rakyat Oemar Hamalik. 2001. Proses Belajar Mengajar. Bandung : Bumi Aksara.

Slameto. 2003. Belajar dan Faktor-Faktor yang Mempengaruhinya. Jakarta: Rineka Cipta.

Siti Marliah Tambunan. 2006."Hubungan Antara Kemampuan Spasial dengan Prestasi Belajar Matematika". Makara, Sosial Humaniora, 9(1),27-32. 